\title{
Endovascular Treatment of Traumatic Arteriovenous Fistula in Young Adults with Pulsatile Tinnitus
}

\author{
Hyun Sik Kim, Joon Ho Song, Jae Keun Oh, Jun Hyong Ahn, Ji Hee Kim, In Bok Chang \\ Department of Neurosurgery, Hallym University Sacred Heart Hospital, Anyang, Korea
}

Traumatic arteriovenous fistulas (AVFs) involving the external carotid artery are exceedingly rare in young adults. Since an AVF is the most common life-threatening cause for pulsatile tinnitus (PT), meticulous evaluation and treatment of patients with PT is crucial. Here, we present two traumatic AVF cases treated with coil embolization leading to no residual fistulous connections followed by an immediate and complete resolution of PT. A 20-year-old man developed left ear tinnitus three months after a traumatic brain injury involving the right temporal bone fracture. Cerebral angiography demonstrated an enlarged left middle meningeal artery (MMA) and a fistular point at the posterior branch of the MMA draining to the middle meningeal vein (MMV) and the left pterygoid plexus, suggesting an AVF. Another 18-year-old girl developed left tinnitus, left exophthalmos, and conjunctival injection 6 months after a traffic accident involving no demonstrable abnormal findings in the radiologic exam. Magnetic resonance angiography demonstrated a markedly dilated left MMA draining to the MMV, left cavernous sinus, and left superior ophthalmic vein. In both cases, coil embolization was performed with total obliteration of the fistular point.

Key Words : Arteriovenous fistula · Embolization · Tinnitus · Meningeal artery.

\section{INTRODUCTION}

Arteriovenous fistula (AVF) is developed by various factors including congenital or developmental defects, rupture of an arterial aneurysm into an adjacent vein, inflammation and trauma. Traumatic AVF involving the middle meningeal artery (MMA) is an uncommon lesion that occurs in about $1.8 \%$ of the head trauma cases and manifests within days of the trauma in about $60 \%$ of the patients and within 3 months in $95 \%$ of the patients ${ }^{6,24,27)}$. AVF Patients could be asymptomatic or could have severe symptoms ranging from headache to fatal intracranial hemorrhage depending on their location and size $^{2,3,8)}$.

Of the many underlying risk factors, a traumatic AVF is also one of the most common causes of pulsatile tinnitus $(\mathrm{PT})^{19)}$. Hence, it is essential to identify these patients at the earliest with high attention to detail and meticulous examination to prevent associated complications such as PT. Radiologic evaluation using contrast-enhanced temporal computed tomography (CT) and brain magnetic resonance angiography (MRA) can help to diagnose AVFs; however, cerebral angiography should be performed for the definitive diagnosis and complete

\footnotetext{
- Received : November 14, 2019 •Accepted : December 17, 2019

- Address for reprints : In Bok Chang

Department of Neurosurgery, Hallym University Sacred Heart Hospital, 22 Gwanpyeong-ro 170beon-gil, Dongan-gu, Anyang 14068, Korea Tel : +82-31-380-1500, Fax : +82-31-380-1900, E-mail : nscib71@hanmail.net, ORCID : https://orcid.org/0000-0001-8003-3264
}

This is an Open Access article distributed under the terms of the Creative Commons Attribution Non-Commercial License (http://creativecommons.org/licenses/by-nc/4.0) which permits unrestricted non-commercial use, distribution, and reproduction in any medium, provided the original work is properly cited. 
understanding of the characteristics and classification of $\mathrm{AVFs}^{7)}$.

Traumatic AVFs can be managed in a variety of ways including surgical resection, endovascular embolization, radiation therapy, a combination of these therapies, and observation alone $e^{7,9)}$. A treatment modality should be chosen and personalized according to the specific characteristics and classification of AVFs. Here, we present two traumatic AVF cases treated with coil embolization leading to no residual fistulous connections followed by complete resolution of PT immediately post the procedure. Additionally, we have reviewed previously reported cases of AVFs formed after head trauma.

\section{CASE REPORT}

\section{Case 1}

A 20-year-old man presented with PT on his left ear, 3 months after head trauma. At the time of trauma, a non-contrast brain and facial CT demonstrated a longitudinal fracture of the right temporal bone including hemorrhage in the middle ear and an epidural hematoma in the right temporal lobe area (Fig. 1). Brain MRA demonstrated a fistulous connection between the left external carotid artery and the left middle meningeal vein (MMV) that was suggestive of an AVF. A transfemoral cerebral angiography (TFCA) confirmed the formation of an AVF between the left MMA and the left MMV draining to the left pterygoid plexus with no retrograde flow into the normal subarachnoid veins. The MMA was accessed using an Excelsior SL-10 microcatheter (Stryker, Kalamazoo, MI, USA) and trans-arterial coil embolization was performed on the fistulous point of the left MMA posterior branch (Fig. 2). Six coils were inserted during the procedure. Post-procedure angiography showed no residual fistulous connections. Left PT showed complete resolution immediately after coil embolization.
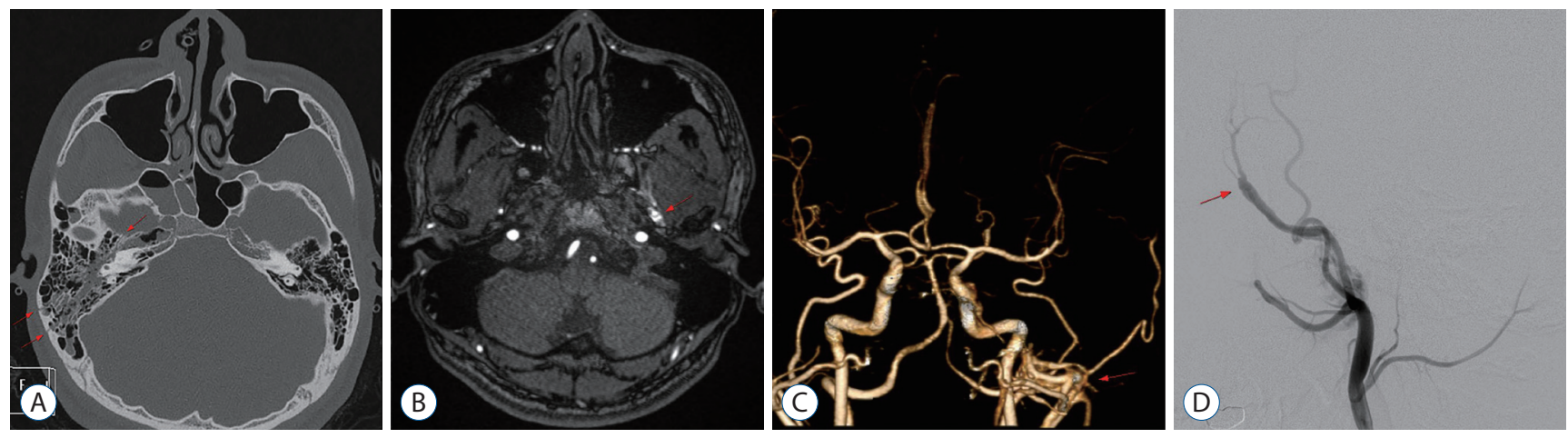

Fig. 1. A 20-year-old man developed pulsatile tinnitus on his left ear 3 months after head trauma. A : Facial CT demonstrates longitudinal fractures on right temporal bone and hemorrhage in right middle ear (arrows). B : Brain MRA demonstrates dilatation of left MMA (arrow). C : Brain CT angio demonstrates fistulous connection between left external carotid artery and left pterygoid plexus suggestive of AVF (arrow). D : Transfemoral cerebral angiography demonstrates fistular point between left MMA and MMV (arrow). CT : computed tomography, MRA : magnetic resonance angiography, MMA : middle meningeal artery, AVF : arteriovenous fistula, MMV : middle meningeal vein.
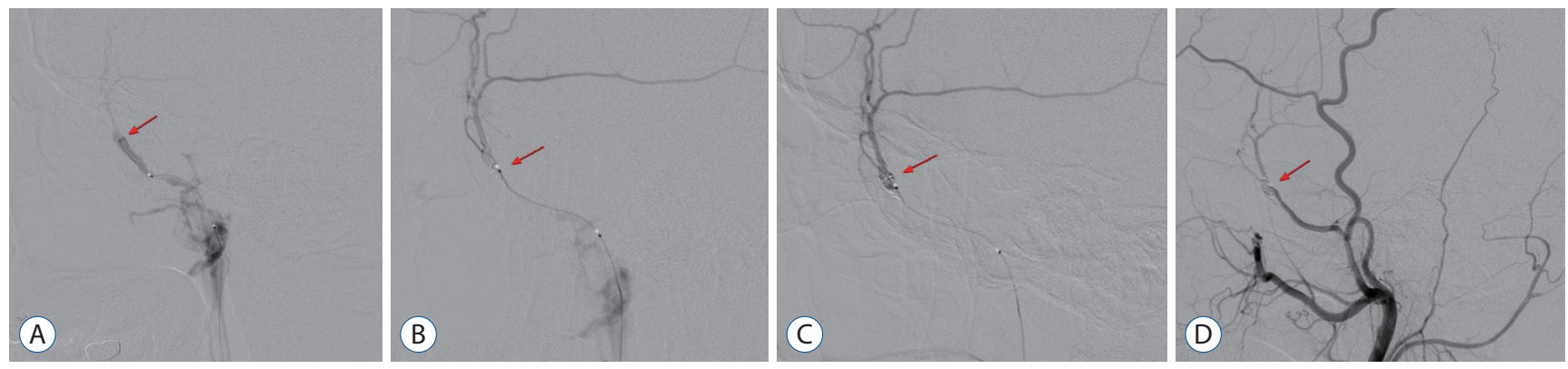

Fig. 2. A : Fistular point is selected with microcatheter (arrow). B : Coil embolization is being done with platinum coil (arrow). C : Total obliteration of fistular point (arrow) is achieved and no visible early venous drainage into middle meningeal vein and pterygoid plexus is confirmed. D : Control angiography shows total obliteration of fistular point (arrow) and arteriovenous fistula is disappeared. 


\section{Case 2}

An 18-year-old girl developed PT on her left ear and left exophthalmos 6 months after a traffic accident. At the time of the accident, a non-contrast brain and facial CT demonstrated no abnormal findings such as fracture and hemorrhage (Fig. 3). However, a brain MRA demonstrated dilatation of the left MMA and the left MMV, suggestive of an AVF. A TFCA confirmed an AVF between the left MMA and the left MMV draining to the cavernous sinus and superior ophthalmic vein with no retrograde flow into the normal subarachnoid. An Excelsior SL-10 microcatheter (Stryker) was used to access the MMA and trans-arterial coil embolization was performed on the fistular point of the left MMA and MMV (Fig. 4). Five coils were inserted during the procedure, after which control angiography showed no residual fistulous connections. Left PT showed complete resolution immediately after the coil embolization and left exophthalmos resolved a week after coil embolization.

\section{DISCUSSION}

Traumatic AVF is characterized by the development of abnormal fistulous connections between the artery and the vein after a head injury. Traumatic AVFs involving the MMA is a rare lesion that occurs in about $1.8 \%$ of the head trauma cases and manifests in $60 \%$ of the patients within days and in $95 \%$ patients within 3 months post injury ${ }^{6}$. Traumatic AVF patients either show a myriad of symptoms including PT, orbital chemosis, orbital proptosis, ocular hypertension, seizures, stroke, otorrhea, and rhinorrhea or are completely asymptomatic. However, distal ischemic symptoms do not develop because of the large amount of collateral circulation in the $\mathrm{MMA}^{27)}$. The above-mentioned symptoms after a head trauma could help neurosurgeons in the successful diagnosis of traumatic AVFs.

In a study carried out between 2003 and 2014 that evaluated 220 patients diagnosed with an AVF, 30 patients (13.6\%) pre-
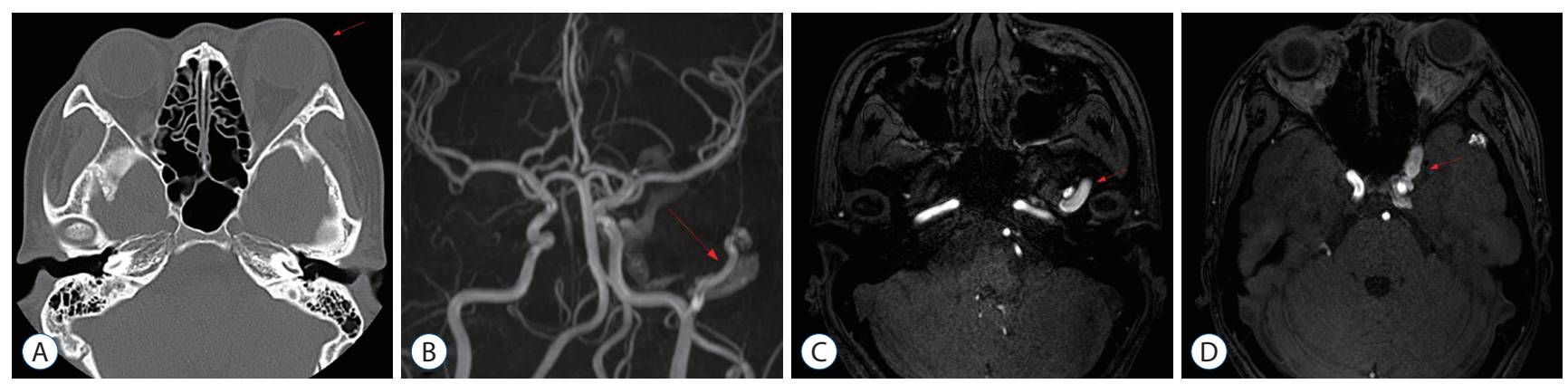

Fig. 3. An 18-year-old girl developed pulsatile tinnitus on left ear 6 months after head trauma. A : Brain CT demonstrates left exophthalmos (arrow). Brain MRA demonstrates dilatation of left MMA (B, arrow) and left MMV (C, arrow) and left cavernous sinus ( $D$, arrow). CT : computed tomography, MRA : magnetic resonance angiography, MMA : middle meningeal artery, $M M V$ : middle meningeal vein.
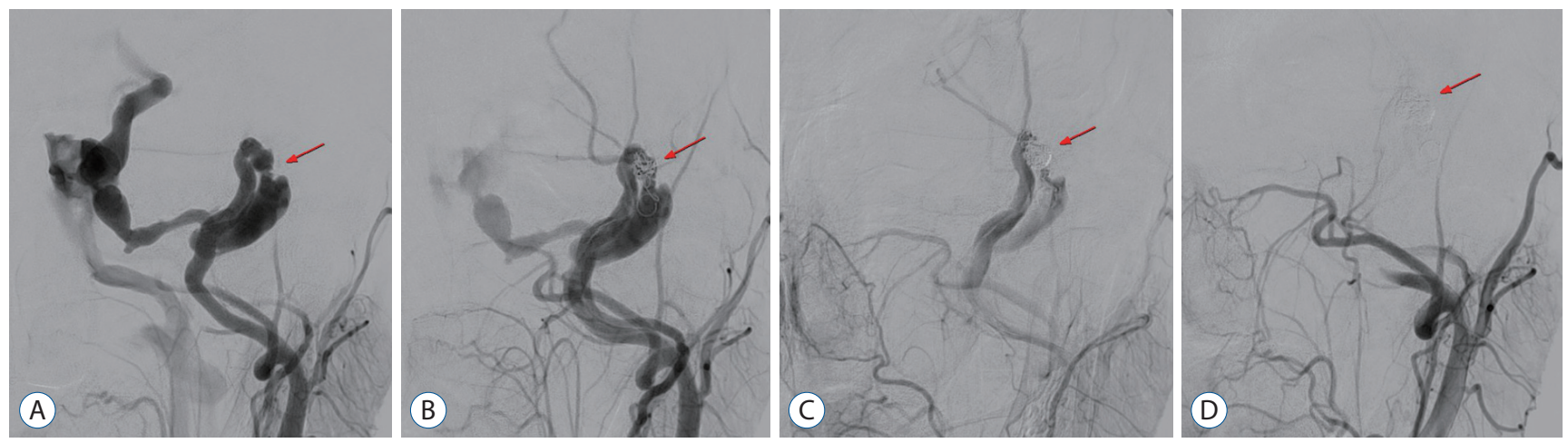

Fig. 4. Transfemoral cerebral angiography was performed. A : Arteriovenous fistula between left MMA and MMV (arrow) draining to left cavernous sinus and superior ophthalmic vein is observed. $B$ and C : Coil embolization is being done with platinum coil (arrow). D : Control angiography shows total obliteration of fistular point (arrow) and no residual venous drainage is found. MMA : middle meningeal artery, MMV : middle meningeal vein. 
sented with only PT as their initial symptom ${ }^{11}$. They reported that PT might be the only initial symptom in more than $10 \%$ of the AVF cases. Since AVFs are the most common lifethreatening cause for PT, not only otolaryngologists but also neurologists and neurosurgeons should meticulously evaluate patients with PT. Although MRA, including time-of-flightangiography, can provide valuable information on an AVF, some recent studies reported that susceptibility-weighted im-

Table 1. Reported cases of fistulas after head trauma between the middle meningeal artery and venous sinus

\begin{tabular}{|c|c|c|c|c|c|c|c|c|}
\hline Study & Trauma & $\begin{array}{l}\text { Age/ } \\
\text { sex }\end{array}$ & $\begin{array}{l}\text { Radiologic } \\
\text { findings }\end{array}$ & $\begin{array}{l}\text { Symptom/ } \\
\text { sign }\end{array}$ & $\begin{array}{c}\text { Interval between } \\
\text { trauma \& } \\
\text { symptom }\end{array}$ & $\begin{array}{l}\text { Involoved } \\
\text { vessels }\end{array}$ & Drainage & Treatment \\
\hline $\begin{array}{c}\text { Fincher }^{5)} \\
(1951)\end{array}$ & $\begin{array}{l}\text { Falling down } \\
\text { on motor } \\
\text { cycle }\end{array}$ & 24/female & Skull Fx. & $\begin{array}{l}\text { Lt. pulsatile } \\
\text { tinnitus }\end{array}$ & 1 month & $\begin{array}{r}\text { MMA \& greater } \\
\text { petrosal sinus }\end{array}$ & N.A. & $\begin{array}{l}\text { Ligation of Lt. } \\
\text { MMA }\end{array}$ \\
\hline $\begin{array}{l}\text { Pakarinen }^{14)} \\
\text { (1965) }\end{array}$ & Quarrel & 25/male & Normal & $\begin{array}{l}\text { Rt. Pulsatile } \\
\text { tinnitus }\end{array}$ & 14 hours & $\begin{array}{r}\text { MMA \& greater } \\
\text { petrosal sinus }\end{array}$ & $\begin{array}{l}\text { Spheno- } \\
\text { parietal sinus }\end{array}$ & $\begin{array}{l}\text { Ligation of } \\
\text { Rt. external } \\
\text { carotid artery }\end{array}$ \\
\hline $\begin{array}{l}\text { Freckmann et } \\
\text { al. }{ }^{6)}(1981)\end{array}$ & Yes & 65/female & FP. Fx. & N.A. & N.A. & $\begin{array}{l}\text { Posterior branch } \\
\text { of MMA }\end{array}$ & N.A. & None \\
\hline $\begin{array}{l}\text { Freckmann et } \\
\text { al. }{ }^{6)}(1981)\end{array}$ & Yes & 40/male & $\begin{array}{l}\text { Sphenoid \& } \\
\text { TO Fx. }\end{array}$ & N.A. & N.A. & $\begin{array}{l}\text { Posterior branch } \\
\text { of MMA }\end{array}$ & N.A. & Surgery \\
\hline $\begin{array}{l}\text { Freckmann et } \\
\text { al. } .^{6}(1981)\end{array}$ & Yes & 62/female & $\begin{array}{l}\text { Sphenoid } \\
\text { Fx. }\end{array}$ & N.A. & N.A. & $\begin{array}{l}\text { Anterior and } \\
\text { posterior branch } \\
\text { of MMA }\end{array}$ & N.A. & Surgery \\
\hline $\begin{array}{l}\text { Freckmann et } \\
\text { al. }{ }^{6)}(1981)\end{array}$ & Yes & 44/female & $\begin{array}{l}\text { Sphenoid } \\
\text { Fx. }\end{array}$ & N.A. & N.A. & $\begin{array}{l}\text { Posterior branch } \\
\text { of MMA }\end{array}$ & N.A. & Surgery \\
\hline $\begin{array}{l}\text { Freckmann et } \\
\text { al. }{ }^{6} \text { (1981) }\end{array}$ & Yes & 47/male & $\begin{array}{l}\text { Sphenoid \& } \\
\text { TFX. }\end{array}$ & N.A. & N.A. & $\begin{array}{l}\text { Posterior branch } \\
\text { of MMA }\end{array}$ & N.A. & None \\
\hline $\begin{array}{l}\text { Freckmann et } \\
\text { al. }{ }^{6)}(1981)\end{array}$ & Yes & 68/male & $\begin{array}{l}\text { Sphenoid \& } \\
\text { TFX. }\end{array}$ & N.A. & N.A. & $\begin{array}{l}\text { Posterior branch } \\
\text { of MMA }\end{array}$ & N.A. & Surgery \\
\hline $\begin{array}{l}\text { Freckmann et } \\
\text { al. }{ }^{6} \text { (1981) }\end{array}$ & Yes & 36/male & $\begin{array}{l}\text { Sphenoid \& } \\
\text { TPO Fx. }\end{array}$ & N.A. & N.A. & $\begin{array}{l}\text { Posterior branch } \\
\text { of MMA }\end{array}$ & N.A. & Surgery \\
\hline $\begin{array}{l}\text { Freckmann et } \\
\text { al. }{ }^{6)}(1981)\end{array}$ & Yes & 44/male & PFX. & N.A. & N.A. & $\begin{array}{l}\text { Anterior branch } \\
\text { of MMA }\end{array}$ & N.A. & None \\
\hline $\begin{array}{l}\text { Unterhofer et } \\
\text { al. }^{23)}(2009)\end{array}$ & $\begin{array}{l}\text { Bicycle } \\
\text { accident }\end{array}$ & 53/male & $\begin{array}{l}\text { Fx. Lt. TP Fx. } \\
\text { SDH, Rt. FTP } \\
\text { EDH, Lt. TP }\end{array}$ & $\begin{array}{l}\text { Lt. pulsatile } \\
\text { exophthalmoss }\end{array}$ & 3 days & $\begin{array}{l}\text { Lt. MMA \& } \\
\text { sphenoparietal } \\
\text { sinus }\end{array}$ & $\begin{array}{l}\text { Cavernous } \\
\text { sinus }\end{array}$ & Coil \\
\hline $\begin{array}{l}\text { Vassilyadi et } \\
\text { al. }^{24)}(2009)\end{array}$ & $\begin{array}{l}\text { Falling down } \\
\text { on bicycle }\end{array}$ & 12/male & $\begin{array}{l}\text { Rt. TP Fx. } \\
\text { EDH on Rt. } \\
\text { FTP }\end{array}$ & Rt. T bruit & 6 weeks & $\begin{array}{l}\text { Rt. MMA \& dural } \\
\text { vein }\end{array}$ & Sigmoid sinus & Glue \& coil \\
\hline $\begin{array}{l}\text { Takeuchi et } \\
\text { al. }^{22)}(2009)\end{array}$ & $\begin{array}{l}\text { Traffic } \\
\text { accident }\end{array}$ & 21/male & Rt. TFx. & $\begin{array}{l}\text { Lt. tinnitus \& } \\
\text { exophthalmos }\end{array}$ & 3 months & $\begin{array}{l}\text { Lt. MMA \& } \\
\text { Lt. middle } \\
\text { meningeal vein }\end{array}$ & $\begin{array}{l}\text { Sphenoparietal } \\
\text { sinus \& } \\
\text { cavernous } \\
\text { sinus }\end{array}$ & $\begin{array}{l}\text { Transarterial } \\
\text { embolization }\end{array}$ \\
\hline $\begin{array}{l}\text { Yu et al. } \\
\text { (2017) }\end{array}$ & $\begin{array}{l}\text { Falling down } \\
\text { on } 4^{\text {th }} \text { floor }\end{array}$ & $8 /$ male & normal & Lt. exophthalmos & 4 months & $\begin{array}{l}\text { Lt. MMA \& } \\
\text { pterygoid } \\
\text { plexus }\end{array}$ & $\begin{array}{l}\text { Cavernous } \\
\text { sinus }\end{array}$ & Onyx \& coil \\
\hline $\begin{array}{l}\text { Martinez et } \\
\text { al. }^{12)}(2018)\end{array}$ & $\begin{array}{l}\text { Traffic } \\
\text { accident }\end{array}$ & N.A. & $\begin{array}{l}\text { Lt. T Fx. } \\
\text { SDH \& SAH } \\
\text { on Lt. FT }\end{array}$ & Lt. tinnitus & 9 weeks & Lt. MMA & $\begin{array}{l}\text { Lt. pterygoid } \\
\text { plexus }\end{array}$ & Coil \\
\hline
\end{tabular}

Fx. : fracture, Lt. : left, MMA : middle meningeal artery, N.A. : not available, Rt. : right, F : frontal, P : parietal, T : temporal, O : occipital, SDH : subdural hemorrhage, FTP : frontotemporoparietal, EDH : epidural hemorrhage 
aging was also sensitive in detecting $\mathrm{AVFs}^{10,13,16)}$. Nevertheless, cerebral angiography remains the gold standard for evaluating and classification of $\mathrm{AVFs}^{4}$.

Traumatic AVFs between the MMA and MMV are uncommon because of the anatomical features of these structures ${ }^{27}$. The MMA branches out from the maxillary artery in the deep area of the neck near the mandible to the temporal fossa. It runs between the lateral pterygoid muscle and sphenomandibular ligament, and enters the cranial cavity through the foramen spinosum. The MMV, which runs parallel to the path of the MMA, emerges from the maxillary vein via the pterygoid plexus. The pterygoid plexus is situated between the temporalis muscle and the lateral pterygoid muscle in the temporal fossa communicating with the cavernous sinus via branches through the foramen Vesalii, foramen ovale, and foramen lacerum. An AVF formation between the MMA and MMV or pterygoid plexus is likely because of its vicinity. It often occurs in the area near the MMA groove, where the MMA passes through the foramen spinosum. The MMA and the MMV are not easily damaged to form an AVF by external traumatic impact, because soft tissues such as the lateral pterygoid muscle and temporalis muscle surround them.

In 1981, Freckmann ${ }^{6}$ divided AVFs of the MMA into six different types on the basis of the angiographic features of the route of drainage : type I, Drainage via the MMV to the pterygoid plexus, characterized by a tram-track appearance of the meningeal vessels; type II, Drainage via the sphenoparietal sinus or a similarly running meningeal vein to the sagittal sinus; type III, Drainage via the sphenoparietal sinus to the cavernous sinus; type IV, Drainage via the MMV and the superior petrosal sinus to the cavernous sinus or the basilar plexus; type V, Drainage via the diploic vein; and type VI, Drainage via the bridging vein to superior sagittal sinus. In our case, the 20-year-old man corresponds to type I and the 18-year-old girl corresponds to type IV according to their venous drainage patterns.

A few reports on traumatic AVFs involving MMA have been summarized in Table 1. All these patients had radiologic abnormalities including skull fractures or intracranial hemorrhages except in two cases. All the cases presented radiologic abnormalities and clinical symptoms on the same side until 2009, when Takeuchi et al. ${ }^{22)}$ reported a rare case with temporal bone fracture on the right side, but tinnitus and exophthalmos on the left side. In our case, the 20-year-old man had a skull fracture on the right and PT on the left side. Of the 15 patients in the table, only two had no abnormal findings in the radiologic evaluation. Incidentally, in our case as well, the 18-year-old girl had no abnormal findings as per the radiologic examination at the time of head trauma. The interval between a head trauma and symptom onset usually varies from 14 hours to 4 months as reported in Table 1 . In our case, there was a 3 and 6-month interval period in the 20-year-old man and the 18-year-old girl respectively. From 1951 to 1981, open surgery was performed to treat AVFs, but after 2009, endovascular treatment became more predominant. In line with this, transarterial coil embolization was our choice of treatment.

When fistulas form near the ear, the patient can hear whooshing sounds in line with the cardiac circle, called PT. Tinnitus is the misperception of sound without a corresponding external stimulation and the arterial pulse synchronous PT is usually vascular in origin ${ }^{15,17,18,25)}$. Although PT is uncommon with an incidence of less than $10 \%$ of all tinnitus ${ }^{21)}$, it is important to find the cause of tinnitus because vascular abnormalities are surgically curable and symptoms could be resolved completely ${ }^{11,20,21,26)}$. Avoiding misdiagnoses in patients with PT of vascular origin are crucial to prevent the eventual fatalities caused by the ruptured vessels.

\section{CONCLUSION}

Although traumatic AVFs between the MMA and cranial venous system are rare, doctors should have a high index of suspicion when patients complain of PT or other symptoms after a traumatic brain injury. Attention to detail and meticulous examination are essential to diagnose patients with PT by not only otolaryngologists but also neurologists and neurosurgeons. Cerebral angiography is the diagnostic modality of choice and endovascular treatment could be a safe and effective treatment option for the complete resolution of an AVF followed by that of PT in these patients.

\section{CONFLICTS OF INTEREST}

No potential conflict of interest relevant to this article was reported. 


\section{INFORMED CONSENT}

Informed consent was obtained from all individual participants included in this study.

\section{AUTHOR CONTRIBUTIONS}

\author{
Conceptualization : IBC, HSK \\ Data curation : IBC, HSK \\ Formal analysis : JHA, JHK, IBC, HSK \\ Methodology: JHS, JKO, HSK \\ Project administration : HSK, IBC \\ Visualization : HSK \\ Writing - original draft : HSK \\ Writing - review \& editing : IBC
}

\section{ORCID}

$\begin{array}{ll}\text { Hyun Sik Kim } & \text { https://orcid.org/0000-0003-0639-4162 } \\ \text { Joon Ho Song } & \text { https://orcid.org/0000-0001-6772-1118 } \\ \text { Jae Keun Oh } & \text { https://orcid.org/0000-0001-5127-2661 } \\ \text { Jun Hyong Ahn } & \text { https://orcid.org/0000-0002-8529-6757 } \\ \text { Ji Hee Kim } & \text { https://orcid.org/0000-0001-6937-8093 } \\ \text { In Bok Chang } & \text { https://orcid.org/0000-0001-8003-3264 }\end{array}$

\section{References}

1. An YH, Han S, Lee M, Rhee J, Kwon OK, Hwang G, et al. : Dural arteriovenous fistula masquerading as pulsatile tinnitus: radiologic assessment and clinical implications. Sci Rep 6 : 36601, 2016

2. Borden JA, Wu JK, Shucart WA : A proposed classification for spinal and cranial dural arteriovenous fistulous malformations and implications for treatment. J Neurosurg 82 : 166-179, 1995

3. Cognard C, Gobin YP, Pierot L, Bailly AL, Houdart E, Casasco A, et al. : Cerebral dural arteriovenous fistulas: clinical and angiographic correlation with a revised classification of venous drainage. Radiology 194 : 671-680, 1995

4. Deuschl C, Göricke S, Gramsch C, Özkan N, Lehnerdt G, Kastrup O, et al. : Value of DSA in the diagnostic workup of pulsatile tinnitus. PLoS One 10 : e0117814, 2015

5. Fincher EF : Arteriovenous fistula between the middle meningeal artery and the greater petrosal sinus; case report. Ann Surg 133 : 886-888, 1951

6. Freckmann N, Sartor K, Herrmann HD : Traumatic arteriovenous fistulae of the middle meningeal artery and neighbouring veins or dural sinuses. Acta Neurochir (Wien) 55 : 273-281, 1981

7. Gandhi D, Chen J, Pearl M, Huang J, Gemmete JJ, Kathuria S : Intracranial dural arteriovenous fistulas: classification, imaging findings, and treatment. AJNR Am J Neuroradiol 33 : 1007-1013, 2012

8. Geibprasert S, Pongpech S, Armstrong D, Krings T : Dangerous extracranial-intracranial anastomoses and supply to the cranial nerves: vessels the neurointerventionalist needs to know. AJNR Am J Neuroradiol 30 : 1459-1468, 2009

9. Kiyosue H, Hori Y, Okahara M, Tanoue S, Sagara Y, Matsumoto S, et al. : Treatment of intracranial dural arteriovenous fistulas: current strategies based on location and hemodynamics, and alternative techniques of transcatheter embolization. Radiographics 24 : 1637-1653, 2004

10. Letourneau-Guillon L, Krings T : Simultaneous arteriovenous shunting and venous congestion identification in dural arteriovenous fistulas using susceptibility-weighted imaging: initial experience. AJNR Am J Neuroradiol 33 : 301-307, 2012

11. Lockwood AH, Salvi RJ, Burkard RF : Tinnitus. N Engl J Med 347 : 904-910, 2002

12. Martinez M, Pergami P, Murnick J, Pearl MS : Embolization of a traumatic arteriovenous fistula between the middle meningeal artery and middle meningeal vein in a child with pulsatile tinnitus. Childs Nerv Syst 34 : 571-575, 2018

13. Noguchi K, Kuwayama N, Kubo M, Kamisaki Y, Kameda K, Tomizawa $\mathrm{G}$, et al. : Intracranial dural arteriovenous fistula with retrograde cortical venous drainage: use of susceptibility-weighted imaging in combination with dynamic susceptibility contrast imaging. AJNR Am J Neuroradiol 3 : 1903-1910, 2010

14. Pakarinen $\mathrm{S}$ : Arteriovenous fistula betwwen the middle meningeal artery and the sphenoparietal sinus. A case report. J Neurosurgery 23 : 438-439, 1965

15. Remley KB, Coit WE, Harnsberger HR, Smoker WR, Jacobs JM, Mclff EB : Pulsatile tinnitus and the vascular tympanic membrane: $C T, M R$, and angiographic findings. Radiology 174 : 383-389, 1990

16. Saini J, Thomas B, Bodhey NK, Periakaruppan A, Babulal JM : Susceptibility-weighted imaging in cranial dural arteriovenous fistulas. AJNR Am J Neuroradiol 30 : E6, 2009

17. Sila CA, Furlan AJ, Little JR : Pulsatile tinnitus. Stroke 18 : 252-256, 1987

18. Sismanis A, Smoker WR : Pulsatile tinnitus: recent advances in diagnosis. Laryngoscope 104(6 Pt 1) : 681-688, 1994

19. Söderman M, Pavic L, Edner $G$, Holmin S, Andersson $T$ : Natural history of dural arteriovenous shunts. Stroke 39 : 1735-1739, 2008

20. Song JJ, Kim YJ, Kim SY, An YS, Kim K, Lee SY, et al. : Sinus wall resurfacing for patients with temporal bone venous sinus diverticulum and ipsilateral pulsatile tinnitus. Neurosurgery 77 : 709-717; discussion 717, 2015

21. Stouffer JL, Tyler RS : Characterization of tinnitus by tinnitus patients. J Speech Hear Disord 55 : 439-453, 1990

22. Takeuchi S, Takasato Y, Masaoka H, Hayakawa T, Otani N, Yoshino Y, et al. : A case of traumatic middle meningeal arteriovenous fistula on the 
side of the head opposite to the injured side. No Shinkei Geka 37 : 983-986, 2009

23. Unterhofer $C$, Chemelli $A$, Waldenberger $P$, Bauer $R$, Ortler $M$ : Traumatic fistula between the middle meningeal artery and the sphenoparietal sinus. Acta Neurochir (Wien) 151 : 1301-1304, 2009

24. Vassilyadi M, Mehrotra N, Shamji MF, Michaud J : Pediatric traumatic dural arteriovenous fistula. Can J Neurol Sci 36 : 751-756, 2009

25. Waldvogel D, Mattle HP, Sturzenegger M, Schroth G : Pulsatile tinnitus- -a review of 84 patients. J Neurol 245 : 137-142, 1998

26. Wee JH, Song JJ, Koo JW, Kim CS : Increased intracranial pressure after surgical treatment of pulsatile tinnitus from a prominent sigmoid sinus. Otol Neurotol 33 : e41-e42, 2012

27. Yu J, Guo Y, Wu Z, Xu K : Traumatic arteriovenous fistula between the extracranial middle meningeal artery and the pterygoid plexus: a case report and literature review. Interv Neuroradiol 23 : 90-96, 2017 